\title{
ANALYSIS OF THE TOURISM SECTOR IN INDONESIA USING THE INPUT-OUTPUT AND ERROR-CORRECTION MODEL APPROACH
}

\author{
Albert Hasudungan ${ }^{1}$ \\ Universitas Prasetiya Mulya, Indonesia \\ Dewa Gede Sidan Raeskyesa \\ Kiel Institute for The World Economy, Germany \\ Erica Novianti Lukas \\ Universitas Prasetiya Mulya, Indonesia \\ Fati Ramadhanti \\ Universitas Prasetiya Mulya, Indonesia
}

\begin{abstract}
This research explores the role of the tourism sector in Indonesia, including its backward and forward linkages with other economic sectors. The tourism sector is represented by the hotel and restaurant (hospitality) industry. The study uses the input-output method and traces the econometric backward and forward shocks of the tourism sector with the Error Correction Model (ECM), using database from Statistics Indonesia from 2010 to 2019 . The paper contributes to the existing literature by using multi-stage quantitative processes to observe backward and forward economic linkages. The result shows that manufacturing output contributes a significant and positive effect to the hotel and restaurant industry. At the same time, the tourism sector provides a significant and positive contribution to government retribution. Nonetheless, there is a negative relationship between the growth of the agriculture and tourism sector, which is assumed due to the tradeoff in the factor of production between the agricultural and tourism sector development. Consequently, backward and forward relationships suggest more holistic and prudent economic policies for observing interdependent tourism development in Indonesia's other economic sectors.
\end{abstract}

JEL : B23, D57, Z32

Keywords : input output, economic impact of tourism, ECM, economic development, Indonesia.

\begin{abstract}
ABSTRAK
Tujuan penelitian ini adalah menginvestigasi keterkaitan ke belakang dan ke depan antara sektor pariwisata dan sektor ekonomi lain di Indonesia. Pariwisata di sini di wakili sektor perhotelan dan restoran. Studi ini menggunakan metode input-output dengan data berasal dari database input output Bank Pembangunan Asia (ADB). Kedua, studi menelusuri keterkaitan ekonometrik ke depan dan ke belakang pariwisata dengan model koreksi kesalahan (ECM), menggunakan data triwulan dari PDB riil di database BPS dari tahun 2010 hingga 2019. Kontribusi makalah ini adalah proses multiasesment untuk mengamati keterkaitan ekonomi ke belakang dan ke depan antara pariwisata dengan sektor ekonomi lainnya. Dari ekonometri tersebut, diketahui bahwa kontribusi output industry manufaktur berpengaruh signifikan dan positif terhadap industri hotel dan restoran. Selain itu, pariwisata memberikan kontribusi yang signifikan dan positif untuk retribusi pemerintah. Meskipun demikian, peningkatan output pariwisata datang dengan pengorbanan pengurangan output sektor pertanian. Hal ini dipengaruhi oleh kompetisi akses faktor produksi di antara kedua sektor tersebut. Hasil ini menekankan perlunya kebijakan ekonomi yang lebih holistik dan hati-hati terhadap saling ketergantungan antara pembangunan pariwisata dengan sektor ekonomi lain di Indonesia.
\end{abstract}

Kata Kunci : analisis input output, dampak sektor pariwisata, ECM, ekonomi pembangunan, Indonesia

\footnotetext{
${ }^{1}$ Email : albert.hasudungan@pmbs.ac.id

Received : 12-01-2021, Accepted : 14-04-2021, Published : 29-04-2021

P-ISSN : 2087-9954, E-ISSN : 2550-0066. DOI : http://dx.doi.org/10.26418/jebik.v10i1.44329
} 


\section{INTRODUCTION}

From a global perspective, the tourism sector shows a positive trend in its impact on the economy. The United Nations World Tourism Organization (UNWTO) has recorded that total international tourist arrivals increased to $5 \%$ or 1.4 billion in 2018. On the other side, the export income created by tourism has risen to USD 1.7 trillion. This trend has made the tourism sector a significant force for economic growth (UNWTO, 2019).

In Indonesia, the tourism sector has also experienced positive development and played a significant role in the country's economy. As recorded, tourist arrivals increased from around 8 million visitors in 2013 to more than 14 million by 2018 (Figure 1), which places Indonesia in fourth place among the Association of Southeast Asian Nations (ASEAN) member countries (Figure 1). Moreover, the tourism sector's contribution to gross domestic product (GDP) has gradually increased, from $4.13 \%$ in 2015 to 6\% in 2018 (Statistics Indonesia, 2019; World Travel and Tourism Council, 2019). One contribution from the tourism sector to Indonesia's GDP comes from the revenue generated by tourists at the tourism destination or the amount spent by tourists when they visit Indonesia. Based on Statistics Indonesia (2019), the average amount spent per visit in United States dollars by foreign tourists increased by $31.5 \%$ from 2006 to 2016 , from $\$ 913.1$ to $\$ 1,201$. This spending contributed about $\$ 11$ billion to Indonesia's economy in 2014. Many of these foreign tourists came from Saudi Arabia, the Netherlands, Italy, and Australia, among others (as shown in Figures 1 and 2).

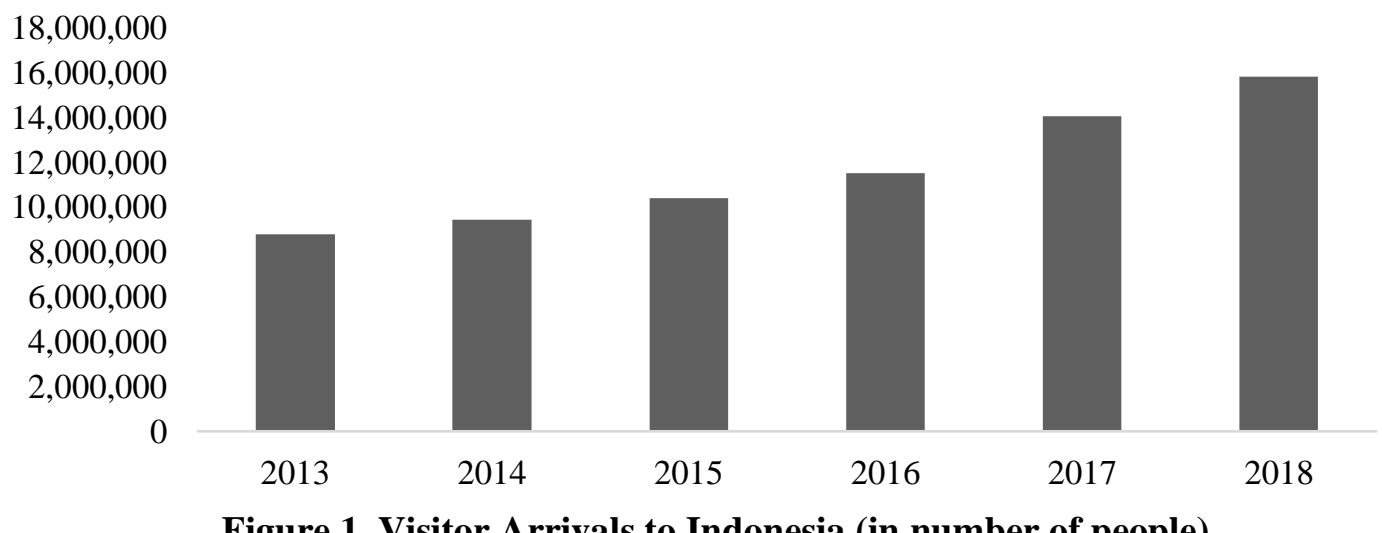

Figure 1. Visitor Arrivals to Indonesia (in number of people)

Source: ASEAN Statistics (author's calculation)

According to the Ministry of Tourism (2018), the tourism sector's contribution to the GDP during each year from 2015 to 2018 was $4.25 \%, 4.13 \%, 5 \%$, and $5.25 \%$, respectively. In other words, it shows an upward trend in the tourism sector's contribution to Indonesia's GDP. Moreover, tourism contributes to the country's macroeconomic performance and Indonesians' welfare as household consumption increased (Blake, Sinclair, \& Sugiyarto, 2003). Thus, it is not surprising that the Indonesian government has made the tourism sector one of the top five industries to be developed in the National Medium-Term Development Plan 2015 - 2019 (BAPPENAS, 2015). This commitment is shown through, for example, extensive development of 10 priority destinations, which are also known as "10 New Bali," followed by significant investment in the infrastructure and establishment of an ecosystem that accounts for up to IDR 234 billion and IDR 227.6 billion for budget allocation in 2018 and 2019, respectively (Ministry of Tourism, 2018b). 


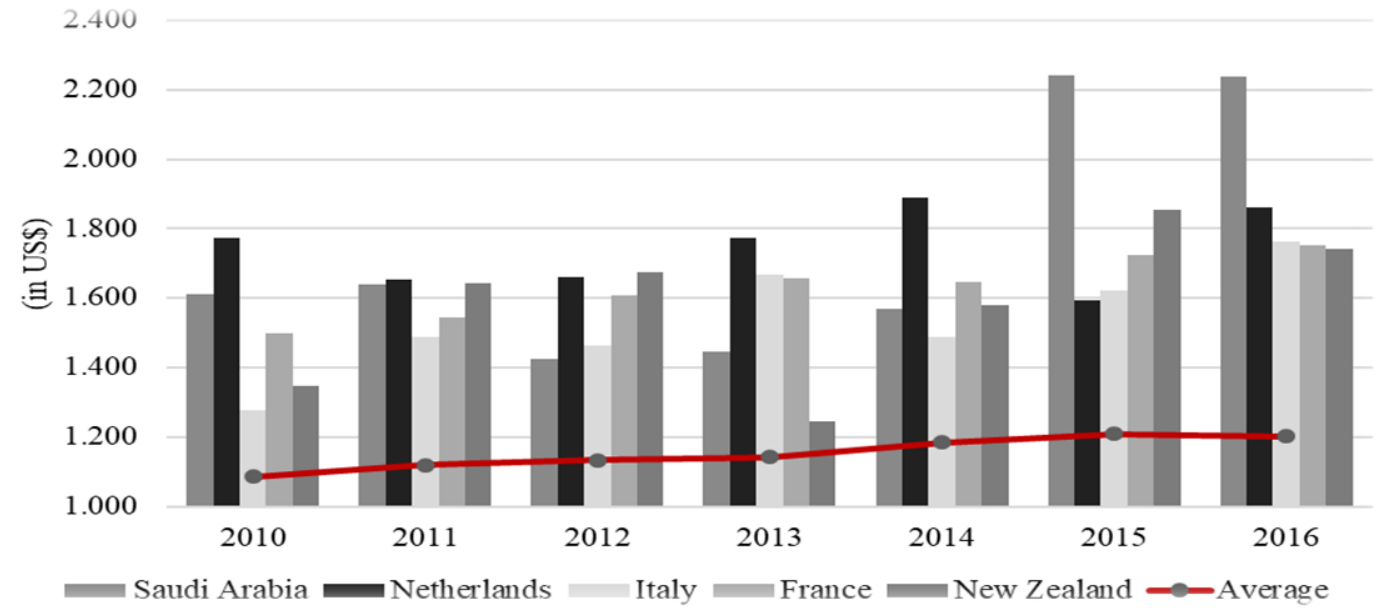

Figure 2. Amount of Spending per Visit by Country

Source: Statistics Indonesia, 2020 (author's calculation)

The growing importance of the tourism sector motivates this study to assess its role among other Indonesian economy sectors. The study aims to increase the general understand of the impact and the development of the tourism sector, which is essential for policymaking. Past studies in Indonesia tend to use single-stage reviews of input-output to trace backward and forward linkages between tourism and other sectors (Antara, 2008; Atan \& Arslanturk, 2012; Saputra \& Kurniawan, 2012; Singagerda \& Septarina, 2016). However, this study analyzes comprehensively backward and forward shocks to and from tourism using the multi-stage process. Firstly, the study uses multiyear input-output to observe the backward and forward tourism economic linkage's economic multiplier. After that, the significance of backward and forward econometric influence can be estimated through the ECM model (Enders, 2014; IHS Markit, 2017).

Based on empirical analysis, the results show the positive interdependence of the manufacturing, tourism, and government output share contribution. Nonetheless, there is a tradeoff in the factor of productions between tourism and agriculture. The expansion of hotel, restaurant, and agriculture cash crops requires land access to expand their economies. These findings should be taken into account as Indonesia has still sustained cash crops (e.g., coffee, cacao, and oil palm) as a significant economic export contribution (Neilson, Pritchard, Fold, \& Dwiartama, 2018), and the agricultural sector is found to be significant to reduce the country's inequality (GonzálezGordon, Resosudarmo, 2019; Raeskyesa, 2020). Thus, this study underscores the prudent and holistic perspectives of observing the tourism sector and other economic sectors in Indonesia.

This paper comprises several sections. After the introduction, the rest of the paper is structured as follows: the literature review is presented in the second section, then the input-output analysis is described in section 3. Sections 4 and 5 consist of the empirical results and conclusion, respectively.

\section{LITERATURE REVIEW}

\subsection{Backward Economic Linkage of Tourism Sector}

In regional economic development, backward linkage describes the dependency of one particular sector's outputs to the other sectors' output as the input of the particular production 
(Jansen, Stern, \& Weiss, 2015). In particular, tourism relies on different sectors as part of its raw materials and service support.

In global studies, several studies examine the backward linkage of the tourism sector with other economic sectors. For instance, based on past studies, the tourism industry requires food and raw materials from the agricultural and manufacturing industries (Jansen et al., 2015; Kim \& Kim, 2015). In addition, Kronenberg, Fuchs, \& Lexhagen (2018) explain that tourism relies on whole trade to intermediate access to raw material inputs from the manufacturer. In some developing economies, the growth of cash crops and tourism are both competing economic drivers. For instance, the Indonesian oil palm export has played an essential role in driving Indonesia's export trade balance (Schouten \& Bitzer, 2015). Oil palm has been used as a raw material for food manufacturing products from Indonesia and Malaysia (FAO, 2020). Nonetheless, tourism has been particularly important to bring employment and income diversification for households in developing economies. The contradiction arises when both sectors require land to expand the industry. For instance, oil palm requires a considerable amount of land within its cultivating area (Hasudungan \& Neilson, 2020). On the other hand, the hospitality industry requires land expansion, and some companies have converted some coastal areas for hospitality use (Fabinyi, 2020). Hence, it seems that the interdependence of tourism and agricultural land use has been conflicted in the extant literature.

Past studies of different provinces in Indonesia have demonstrated significantly higher backward impacts or dependencies from other sectors. For example, Singagerda \& Septarina (2016) study investigated this backward linkage in Lampung province. They concluded that the tourism sector had a higher value in backward versus forward linkages. With a dispersion coefficient $>1$, the tourism sector nurtures growth in upstream sectors. In other words, this sector is placed in a downstream position. Furthermore, in the sub-sector analysis, Singagerda \& Septarina, (2016) argued that, despite the sub-sectors' low ability to generate growth downstream, the multiplier effect on employment increased to $32.21 \%$ in 2015 (Singagerda \& Septarina, 2016). Furthermore, in a study conducted in the Sumatra region, Arianti (2014) found similar results in which the tourism sector in the Bukittinggi regency had more significant value in backward than in forward linkages. Moreover, based on the dispersion index analysis's sensitivity, sectors such as transportation, trade, and retail significantly influence the tourism sector in Bukittinggi (Arianti, 2014). Moreover, for the eastern part of Indonesia, Malba \& Taher (2016) found that the tourism sector in Maluku province was mainly related to the air transportation, water transportation, other business sectors, and the hotel and restaurant sectors. They found that the air transportation sector produced its highest value in the output multiplier, which means that this sector's development is essential to increasing the tourism sector's growth.

Furthermore, the tourism sector plays a vital role in the other major provinces in Indonesia, such as Bali and Yogyakarta. Antara (2008), who utilized the input-output method, concluded that the small tourism enterprise sector in Bali had indirect backward and upward linkage value greater than 1.0, which means the sector has development prospects (Antara, 2008). In other words, the tourism sector is essential to foster regional economic development in Bali. Furthermore, as Raeskyesa, Suryandaru \& Kadarusman (2019) reported, most developed regencies in Bali, including Badung and Denpasar, have relied on sub-sectors in tourism, such as food and accommodations, information, and communication, to generate their economic growth (Raeskyesa 
et al. 2019). In addition, the development tourism sector in the Badung region has helped to decrease the poverty level (Patera, Sukarsa, \& Wiranatha, 2015).

Meanwhile, Saputra \& Kurniawan (2012) concluded that, in Yogyakarta, based on the contribution to the total final demand structure, the tourism sector placed first among other economic sectors. On the other hand, in terms of land-use change, it can be concluded to be the reverse development of tourism and agriculture (Pratama \& Rosyidie, 2017). For instance, Pratama \& Rosyidie (2017) find that the tourism industry's expansion has increased demand for construction and conversion of agricultural land into tourism areas. Moreover, based on the dispersion index, economic sectors such as the trade and restaurant sectors had a value greater than 1, which means those sectors are substantial sub-sectors in tourism (Saputra \& Kurniawan, 2012). This result is not surprising, as Yogyakarta has a significant number of tourism sites and possibilities for development in terms of both authentic products such as herbal drinks (Jamu) and community (village)-based tourism, as reported by Hadi (2019) and Suharto (2019). Of course, these hotels and restaurants require materials such as herbs from small processing manufacturing (Suharto, 2019).

With those mixed results of backward linkage of tourism in past studies, the first hypothesis is the interdependent influence of agriculture, trade, and manufacturing output shares with Indonesia's tourism industry.

\subsection{Forward Economic Linkage of Tourism Sector}

Forward linkage analysis explains the positive contribution of tourism to other sectors' output in the economy (Amir \& Nazara, 2005). The extensive relationship of the shock from the tourism sector to broader economic development has been acknowledged; in fact, tourism is argued to be an engine for economic growth. This statement is based on valid research; for example, Dogru \& Bulut (2018) found that, in seven European countries, the tourism sector led to economic growth, and investment in other economic sectors helped increase tourism development. In other words, a strong link exists between economic growth and the tourism sector (Dogru \& Bulut, 2018). Another study concludes that tourism-led growth existed in the top 10 tourist destinations (Shahzad, Shahbaz, Ferrer \& Kumar, 2017). Both of these studies suggest that tourism can contribute significantly to the overall economy during economic downturns. Furthermore, tourism can contribute to the actual value added to the economy. Thus, to better understand the role of the tourism sector in the economy, several studies have been conducted to analyze the contribution of the tourism sector to other sectors, especially in developing and middle-income countries.

Pratt (2015) analyzed the role of the tourism sector in seven small-island developing states (SIDS). The study found that the output multiplier ranged from 1.06 to 2.11 , and for every $\$ 1$ spent by international tourists in those states, only $\$ 0.69$ on average remained in the local economy. As for the linkage analysis, the tourism sector (accommodations and restaurants) had low forward linkages compared to the manufacturing sector, whereas in terms of backward linkages, the sector had a value greater than 1 point. In other words, the tourism sector creates a strong demand for goods and services from other sectors, which generates a decent amount of economic activities (Pratt, 2015). Atan \& Arslanturk (2012) reported a similar result. That study concluded that tourism had a decent impact on the Turkish economy, where the output multiplier of the tourism sector was 1.8966 for hotels and restaurants, which means the sector had significant backward linkages to other sectors and nurtured the related other sectors (Atan \& Arslanturk, 2012). 
Meanwhile, by using input-output analysis and hotel and restaurant data as tourism indicators, Surugiu (2009) found that Romania experienced a decrease in its forward linkage values, dropping from 1.91 in 2000 to 1.07 in 2005 . This means the tourism sector had low economic interdependence. Moreover, in terms of value-added and income, the sector showed a decrease between 2000 and 2005. However, in terms of employment multiplier for hotels and restaurants, the sector increased its ranking from ninth position in 2000 to 5th in 2005, during which an increase of one thousand in the final demand within the sector will result in up to a 0.023 increase in demand for employees (Surugiu, 2009).

With that multiplier effect on income, tourism will have implications for government revenues. In most world economies, employees are levied with the tax from their salaries (Sá, Martins, \& Gomes, 2014). The increasing employee multipliers will give indirect tax benefits to government revenue. In fact, OECD (2020) found that tourism economies have been levied of direct and indirect government retributions and taxes. Hence, tourism contributes to the economy of public sectors in many emerging countries (OECD, 2020). In Indonesia, local hotels and restaurants have become essential sources of local revenues and retribution (Djulius, 2018). This retribution can then be used as a local development source in that particular spatial geography (Djulius, 2018).

Within the discussion on economic tourism, the second hypothesis is the positive shock of tourism industry output to the government administration and retributions. In this economic analysis, the tourism sector is represented by hospitality (hotel and restaurant industry, as accrued in the Indonesian Statistics database).

\section{RESEARCH METHODOLOGY}

The methodology to investigate forward and backward linkages comprise input-output and ECM. The input-output analysis traces the interdepence of tourism to and from other sectors, while the ECM investigates the significance of those variables. The input-output framework describes the relationships among different economic sectors over specific periods (Miller \& Blair, 2009). The foundation of input-output analysis is that one economic sector requires input and contributes outputs to other economic sectors. Rather than holding ceteris paribus assumptions, the interaction of different economic sectors is considered to exist in a matrix economic system (Amir \& Nazara, 2005). A matrix system in an input-output table means that the total input equals the total output of the whole economy (Kronenberg et al., 2018). The input-output table shows the production sector, intermediate output, final demand, and total output in the horizontal column; the rows include different economic production sectors, intermediate input, value-added, and total input (Liu \& He, 2016), as shown in Table 1 as follows. 
Table 1. Input-Output Structure

\begin{tabular}{|c|c|c|c|c|c|c|c|c|c|}
\hline & & \multicolumn{5}{|c|}{ Production sector } & \multirow{2}{*}{$\begin{array}{c}\text { Intermediate } \\
\text { output }\end{array}$} & \multirow{2}{*}{$\begin{array}{c}\text { Final } \\
\text { demand }\end{array}$} & \multirow{2}{*}{$\begin{array}{l}\text { Total } \\
\text { output }\end{array}$} \\
\hline & & 1 & $\ldots$ & $\mathrm{J}$ & $\ldots$ & $\mathrm{n}$ & & & \\
\hline \multirow{5}{*}{$\begin{array}{l}\text { Production } \\
\text { sector }\end{array}$} & 1 & & & & & & & & \\
\hline & $\ldots$ & & & & & & & & \\
\hline & $\mathrm{i}$ & & & $X_{i j}$ & & & $\mathrm{X}_{\mathrm{i}}$ & $Y_{i}$ & $\mathrm{X}_{\mathrm{i}}$ \\
\hline & $\ldots$ & & & & & & & & \\
\hline & $\mathrm{n}$ & & & & & & & & \\
\hline \multicolumn{2}{|c|}{ Intermediate input } & & & $X_{. j}$ & & & & & \\
\hline \multicolumn{2}{|c|}{ Value added } & & & $\mathrm{V}_{\mathrm{j}}$ & & & & $\mathrm{Y}=\mathrm{V}$ & \\
\hline \multicolumn{2}{|c|}{ Total input } & & & $X_{j}$ & & & & & \\
\hline
\end{tabular}

Source: Liu \& He, (2016)

From that table, the matrix equation system is then generated as $\mathrm{X}=\mathrm{AX}+\mathrm{Y}$. In that equation system, $\mathrm{X}$ equals the economic sector output, $\mathrm{A}$ stands for the input coefficient matrix, and $\mathrm{Y}$ is the final demand of a particular sector. A consists of $a_{i j}$ matrix technology coefficients. This technological coefficient is calculated as follows:

$a_{i j}=\frac{x_{I J}}{X j}$

Where $x_{I J}$ is the input from sector $\mathrm{i}$ to support sector $\mathrm{j}$, and $\mathrm{X} j$ is the total input required for sector $\mathrm{j}$. To scrutinize the shock in final demand of sector $\mathrm{i}$ to the whole output, the matrix equation is modified as the Leontief matrix equation, as follows:

$\Delta X=(I-A)^{-1} \Delta Y$

Where $\Delta X$ equals changing output, $\Delta Y$ stands for final demand, and the last step is to estimate $(I-A)^{-1}$. The estimated matrix is interpreted as total output changes when there is a shock of final demand from the particular production sector.

This research extends Indonesian input-output studies previously performed based on single-year input-output data (e.g Anas, Tamin, \& Wibowo (2015); Fafurida (2012)). This study benchmarked the multi-year input-output analysis from Kronenberg et al. (2018) of a multi-period input-output analysis in Sweden. The Indonesian's multi-year data of 2010 to 2017 were sourced from the Asian Development Bank's statistical database. This study first observed the output multiplier of different economic sectors, focusing on the tourism industry (e.g., hospitality and business sector). The output multiplier was formulated as follows:

$O_{j}=\sum_{i=1}^{n} a_{i j}$

Where $O_{j}$ is the output multiplier sector $\mathrm{j}$, and $a_{i j}$ is the Leontief coefficient of input sector $\mathrm{i}$ to be absorbed by sector $\mathrm{j}$. After that, the individual analysis of backward and forward linkages of the tourism industry is performed to compare one industry to other industrial sectors in a time series of 2010 and 2017. To trace the individual effect, indirect backward and forward linkages were exercised in this paper. An indirect backward linkage traces the output multiplier when the final demand of a particular sector changes. This is actually the output multiplier. The indirect backward linkage is formulated as follows:

$B(d+i)_{j}=\sum_{i=1}^{n} \quad a_{i j}$ 
Where $\mathrm{B}$ is backward, $\mathrm{d}$ is indirect, $\mathrm{id}$ is indirect, $\mathrm{j}$ is column- $\mathrm{j}, \mathrm{i}$ is row- $\mathrm{i}$, and $a_{i j}$ is the element of the Leontief matrix coefficient $(I-A)^{-1}$. After the backward linkage is calculated, this study reports the indirect (individual) forward linkages of the hospitability industry with other industries.

$F(d+i)_{j}=\sum_{i=1}^{n} a_{i j}$

Where $\mathrm{F}$ is forward, $\mathrm{d}$ is indirect, $\mathrm{j}$ is column- $\mathrm{j}$, $\mathrm{i}$ is row- $\mathrm{i}$, and $a_{i j}$ is an input coefficient as a matrix element A. $a_{i j}$ is the element of the Leontief matrix coefficient $(I-A)^{-1}$. The hypothetical statement is intended to explore the possible economic linkages among the agricultural sector and the manufacturing and tourism industries.

After that, the econometric assessment is conducted to investigate the significant interdependency of the agriculture, trade, manufacturing, tourism, and the shock of tourism to the public sector. Based on past studies, the tourism industry requires food and raw materials from the agricultural and manufacturing industries (Jansen et al., 2015; Kim \& Kim, 2015). Saputra \& Kurniawan (2012) concluded that, based on the contribution to the total final demand structure, the tourism sector placed first among other economic sectors. The government retribution was part of that final demand structure in that input-output system (Saputra \& Kurniawan, 2012). Inputoutput analysis traces the contribution output (GDP) of one sector to others (Nazara, 2005). Hence, backward and forward linkage ECM models are constructed as follow:

Backward $: Y($ tourism $)=f(Y($ agriculture $), Y($ manufacture $), Y($ trade $))$

$\Delta \log (G D P \text { tourism })_{t}=\beta 0_{t}+\beta 1 \Delta \log (G D P a)_{t}+\beta 2 \Delta \log (G D P m)_{t}+$ $\beta 3 \Delta \log (G D P t r)_{t}+E C T_{t-1}$

Forward: $Y$ (Government $)=f(Y$ (tourism)

$\Delta \log (\text { GDP government })_{\mathrm{t}}=\beta 0_{\mathrm{t}}+\beta 1 \Delta \log (\text { GDPtourism })_{\mathrm{t}}+\mathrm{ECT}_{\mathrm{t}-1}$

In that equation, $\mathrm{Y}$ stands for output, GDP stands for real GDP, a is agriculture, $\mathrm{m}$ is manufacture, $\mathrm{tr}$ is trade, $\mathrm{t}$ stands for time, and $E C T_{t-1}$ stands for error correction term on the past term. The data is converted into logarithmic to avoid heteroscedasticity and multicollinearity problems (Xu, Xu, \& Xu, 2016).

Enders (2014) suggests several procedures in ECM assessment. Firstly, the stationary tests examined whether the format of the variable is the first difference or level or as an indication of the cointegrating relationship. This study uses the Phillips Perron (P-P) Test (IHS Markit, 2017). Secondly, the cointegrating relationship is verified through the Engel Granger cointegrating test. ECM, the cointegration, is diagnosed when the lag of the error correction model influences the dependent variable (Engle \& Granger, 1987). Thirdly, the error correction model and Ordinary Least Square (OLS) model are estimated to respectively observe short-term and long-term relationships (Enders, 2014). Furthermore, heteroscedasticity, multicollinearity, and autocorrelation disturbances are assessed against the OLS model (Enders, 2014).

\section{RESULT \& DISCUSSION}

\subsection{Backward Linkage Analysis}

Firstly, the analysis is intended to identify the highest and lowest sector's final demand to the total output of the Indonesian economy. Based on the multiperiod output multiplier trend, the largest economic driver comes from the electricity and gas economic sectors, while its lowest 
economic driver is the agricultural economic sector. Despite having the lowest multiplier effect, the agricultural output multiplier effect fluctuates relatively less than the electricity, gas, and water sectors. This low fluctuation in the agricultural output multiplier trend is similar to that in the hotel and restaurant sectors (see Figure 3 ).

2017

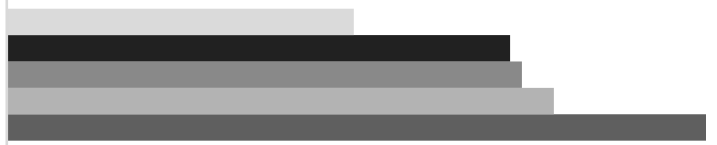

2016

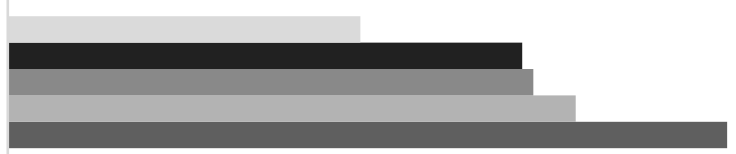

2015

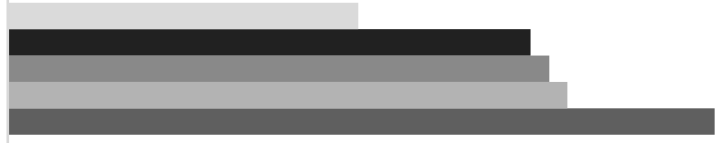

2014

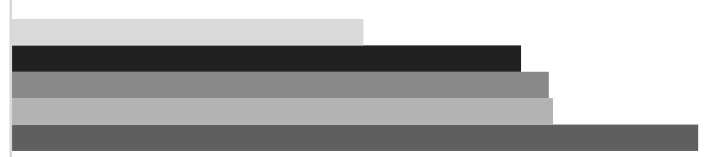

Agriculture, hunting, forestry, and fishing

- Hotels and restaurants

2013

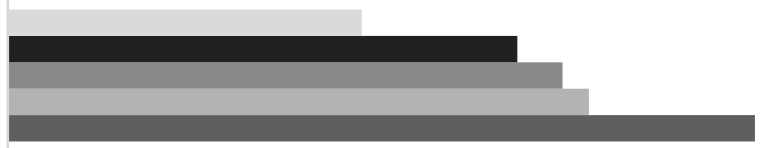

- Food, beverages, and tobacco

Pulp, paper, paper products, printing, and

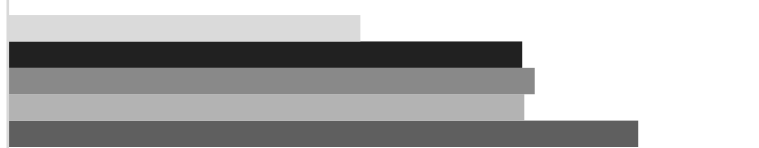
publishing

2011

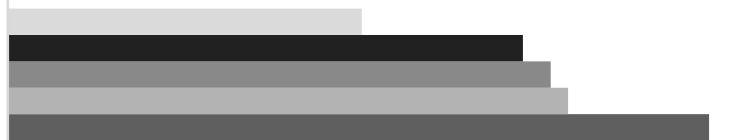

2010

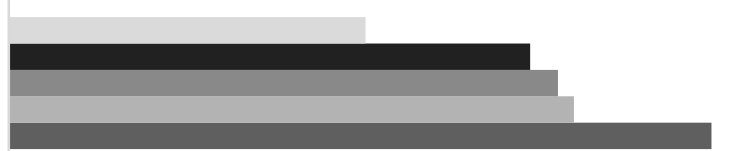
0
$0.5 \quad 1$
$1.5 \quad 2$
2.5
3

Figure 3 Highest and Lowest Output Multipliers in the Entire Economy

Source: Asian Development Bank database, author's calculation

After that, the backward linkage measures the demand driven by a particular sector from other sectors. Based on examination of the hotel and restaurant industry itself, it receives the highest economic input from manufacturing processing (food, beverage, and tobacco), the agricultural sector, and the wholesale trading sector (see Figure 4). While hotels and restaurants require electricity for their operation, they are not the primary inputs for the hotel and restaurant economic sector. In tracing a particular economic sector's output contribution to the entire economy, this study uses aggregate forward-linkage analysis. 
Then, further ECM assessment checks the significant influences of that output share of those sectors to the hotel and restaurant industry (tourism). Firstly, the stationary is checked using the P-P test. The test examines the P-value (and t-statistics) to determine the level or firstdifference stationarity. The stationery test formula is as follows:

$t(\delta)=\frac{\delta}{\operatorname{Se}(\delta)}$.

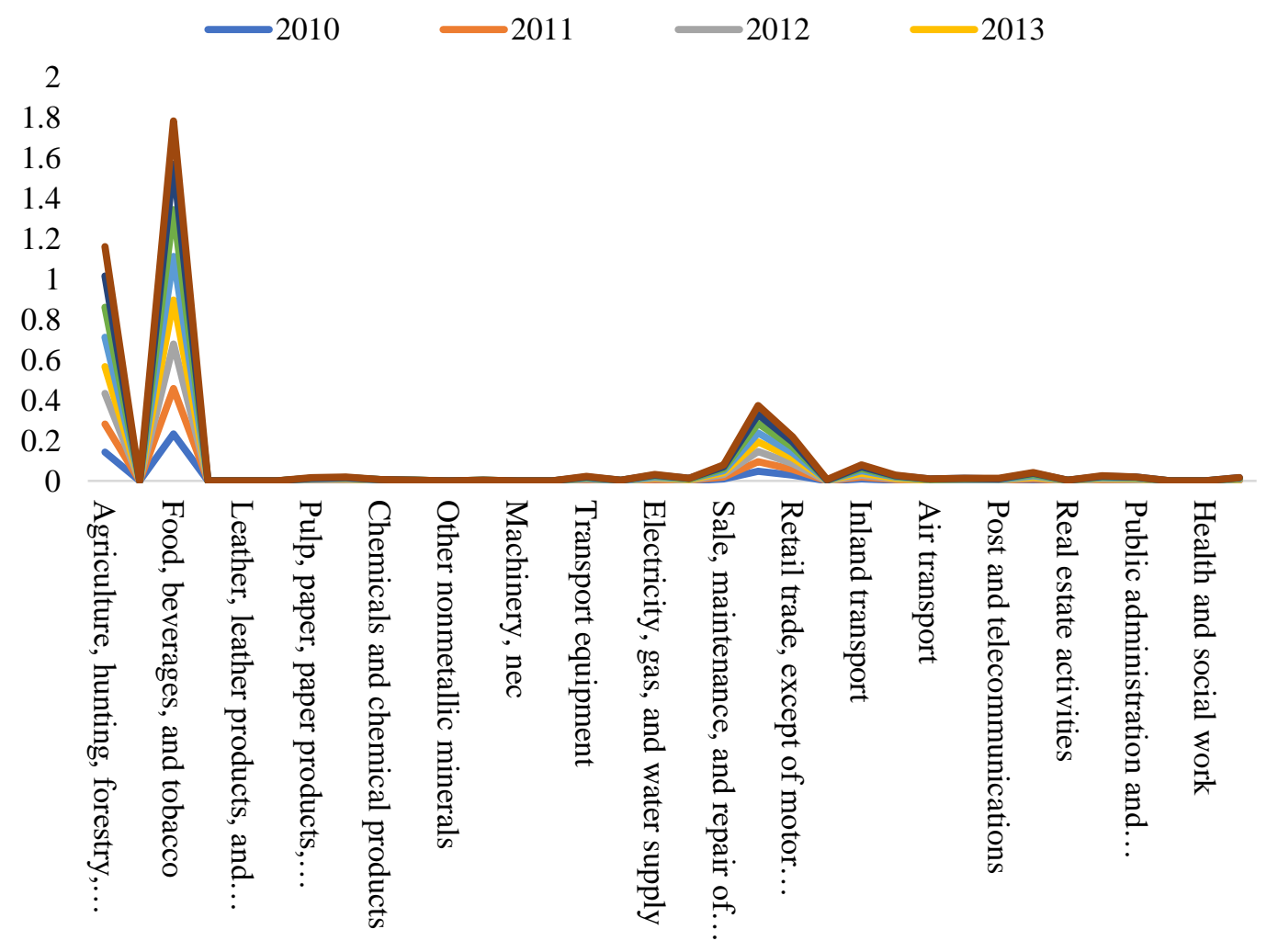

Figure 4 Economic Input Sources for the Hotel and Restaurant Industry

Source: Asian Development Bank database, calculated from matrix technology (A).

Table 1. P-P test in level and first difference

\begin{tabular}{llll}
\hline Variable & P-value & Result & Degree \\
\hline GDP Hotel and Restaurant (Tourism) & 0.4683 & Non-Stationarity & Level \\
GDP Agriculture & 0.0025 & Stationarity & Level \\
GDP Food and Drink manufacturer & 0.5240 & Non-Stationarity & Level \\
GDP of Trade & 0.2987 & Non-Stationarity & Level \\
GDP Hotel \& Restaurant (Tourism) & 0.0000 & Stationarity & First Difference \\
GDP Agriculture & 0.0001 & Stationarity & First Difference \\
GDP Food \& Drink Manufacture & 0.0000 & Stationarity & First Difference \\
GDP of Trade & 0.0000 & Stationarity & First Difference \\
\hline
\end{tabular}

In that equation, $\mathrm{t}$ stands for t-statistics, $\delta$ is the beta coefficient of the observed variables, and Se is the standard error. The null hypothesis relates to the data stationarity, and the alternative hypothesis is non-stationary data (Gujarati \& Porter, 2008). In the level degree, the test results on the non-stationary of the observed variables (see Table 2). Only agriculture output has a stationary condition, while others do not have stationary data. The second stationary examination tests the first difference variables (see Table 3). From that assessment, all variables have data stationarity 
in the first difference level.

The first difference in Table 3 shows an early indication of the cointegrating relationship among the variables. The Engle-Granger cointegration test verifies the cointegrating relationship. In the econometrics' model, the cointegration occurs when the past error correction model significantly affects the error correction of the respective dependent variable (Engle \& Granger, 1987). Based on the cointegration causality test, past error correction disturbance significantly influences the dependent variable's first difference in current error. That test shows the significant influence of the cointegrating relationship in the equation system, as follows:

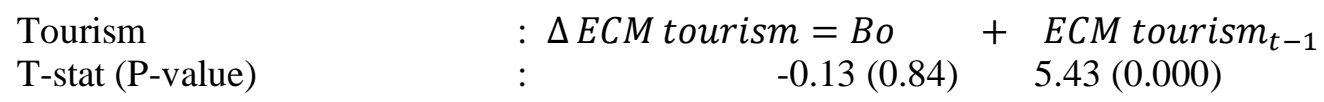

That condition satisfies the long-run cointegrating factor in the original equation (Enders, 2014). Before estimating the regression model, the Breusch-Godfrey heteroscedasticity tests and serial autocorrelation tests are assessed with the original model (IHS Markit, 2017). If the test is insignificant, the heteroscedasticity does not present. For multicollinearity, the test uses VIF (normal variance inflation factor is above).

The econometric assessment found that heteroscedasticity and autocorrelation do not exist, as the tests show the insignificancy of the Breusch-Godfrey (B-G) heteroscedasticity and serial autocorrelation tests $(\mathrm{B}-\mathrm{G}$ Heteroscedasticity P-value $=0.1188$; B-G Serial Correlation test $=$ 0.4660). Nonetheless, there has been multicollinearity among the trade and manufacture output share $($ VIF Trade Sector $=51.73)$. Gujarati \& Porter (2008) state optional consideration to omit or to apply the multicollinearity variable if the multicollinearity appears. In the equation system, if one variable is removed, it disturbs the R-square. Hence, the option is to let the sectors appear. Hence, ECM estimation is shown in Table 3.

Table 2. ECM result of determinants of tourism output (first difference)

\begin{tabular}{cc}
\hline Variables & $\begin{array}{c}\text { Coefficient } \\
(\mathrm{t}-\mathrm{statistics})\end{array}$ \\
\hline$\Delta l$ agricultural output $)$ & $-0.028191^{* *}$ \\
& $(-3.963782)$ \\
$\Delta l$ manufacture output & $0.113040^{* *}$ \\
& $(3.086941)$ \\
$\Delta l$ trade output & 0.065252 \\
& $(1.238976)$ \\
ECT (t-1) & $-0.108347 *$ \\
& $(-1.895657)$ \\
$\Delta l$ tourism $(-1)$ & $0.743332 * *$ \\
R-square & $(11.98874)$ \\
$*$ ) significant at $10 \%, * *)$ significant at $5 \%, l$ stands for logarithm
\end{tabular}

Based on the previous studies (Jansen et al., 2015; Kim \& Kim, 2015), tourism sectors required processing products from the manufacturers. Bali province is famous for its tourism destination, and Raeskyesa et al. (2019) asserts that the agriculture and manufacture sectors play a vital role in most Bali province districts; thus, the tourism sector could rely on products from those sectors.

From these ECM results, it can be concluded that the presence of cointegration is fine. If the significant of lag ECM is 10 percent, but previously the presence of cointegration in equation 
1 and stationarity in table 2 strengthen the cointegration itself, there has been another procedure to check validity post estimation (Chancharoenchai, 2015). To re-check validity of that estimating, we followed the Engel-Granger cointegration tests post-estimation by transforming first the model with cointegration transformation estimation, as suggested by Chancharoenchai (2015) as table 4 :

Table 3. ECM validization

\begin{tabular}{lll}
\hline Test & Value (t-stat) & P-value \\
\hline Engel-Granger Cointegration t-statistics & 6.396 & $0.0040^{* *}$ \\
\hline
\end{tabular}

**) significant at $5 \%$

If the test has significant below 5\%, it proofed the validity of the error correction model of the proposed equation where ECM property appears (Chancharoenchai, 2015). Besides, ECM can be detected with the significance of the lag dependent variable (at an alpha of 5\%). According to our variables, manufacturing output makes a significant and positive contribution to tourism. Based on past studies (Jansen et al., 2015; Kim \& Kim, 2015), tourism sectors required processing products from manufacturers. Suharto (2019) finds that small manufacturing herbs become a vital backbone supplier for the tourism industry in Yogyakarta.

Nonetheless, this study finds that agriculture and tourism have a significant and negative relationship. In a global economy, Krugman, Obstfeld, \& Melitz (2015) describe agriculture as a capital-intensive (land) based economy. Nonetheless, tourisms are more in the servicing sector (Saputra \& Kurniawan, 2012). From a contemporary economic perspective, it was logical when the agriculture sector has expanded; it can reduce the potential availability of land for new hotel and restaurant development in respective geographical areas. In the economic development literature, the development of service sectors on particular geography will take the labor from the agricultural sector (Todaro \& Smith, 2012). Hence, more agricultural expansion in the regional country will limit labor for the tourism sector. Vice versa, the contraction of the agricultural sector will give more labor resources to the tourism sector.

\subsection{Forward Linkage Analysis}

In tracing a particular economic sector's output contribution to the entire economy, this study uses aggregate forward-linkage analysis. When observing the hotel and restaurant industry's output contribution, one can see that it has given the government monetary support in the form of retribution and social security insurance paid to the government over the last eight years, as seen in Figure 5 below.

With that result, the econometric test is performed to measure the shock of the tourism sector on the public-sector economy. As known in the economy, the government retribution and tax levies will be used to develop the social and physical infrastructures to boost the country's GDP (Djulius, 2018). Firstly, the stationary test examines the relationship between variables in the first difference or original level-the test using P-P as shown below. The stationary test shows nonstationarity in level degree, but the variables have the stationarity in the first difference, as seen in Tables 5. After that, the Engel-Granger cointegrating test is performed to validate the cointegrating relationship of that respective variable (IHS Markit, 2017). The test detects the cointegration between the respective variables since the past error correction term significantly affects the current dependent variable error correction term. 


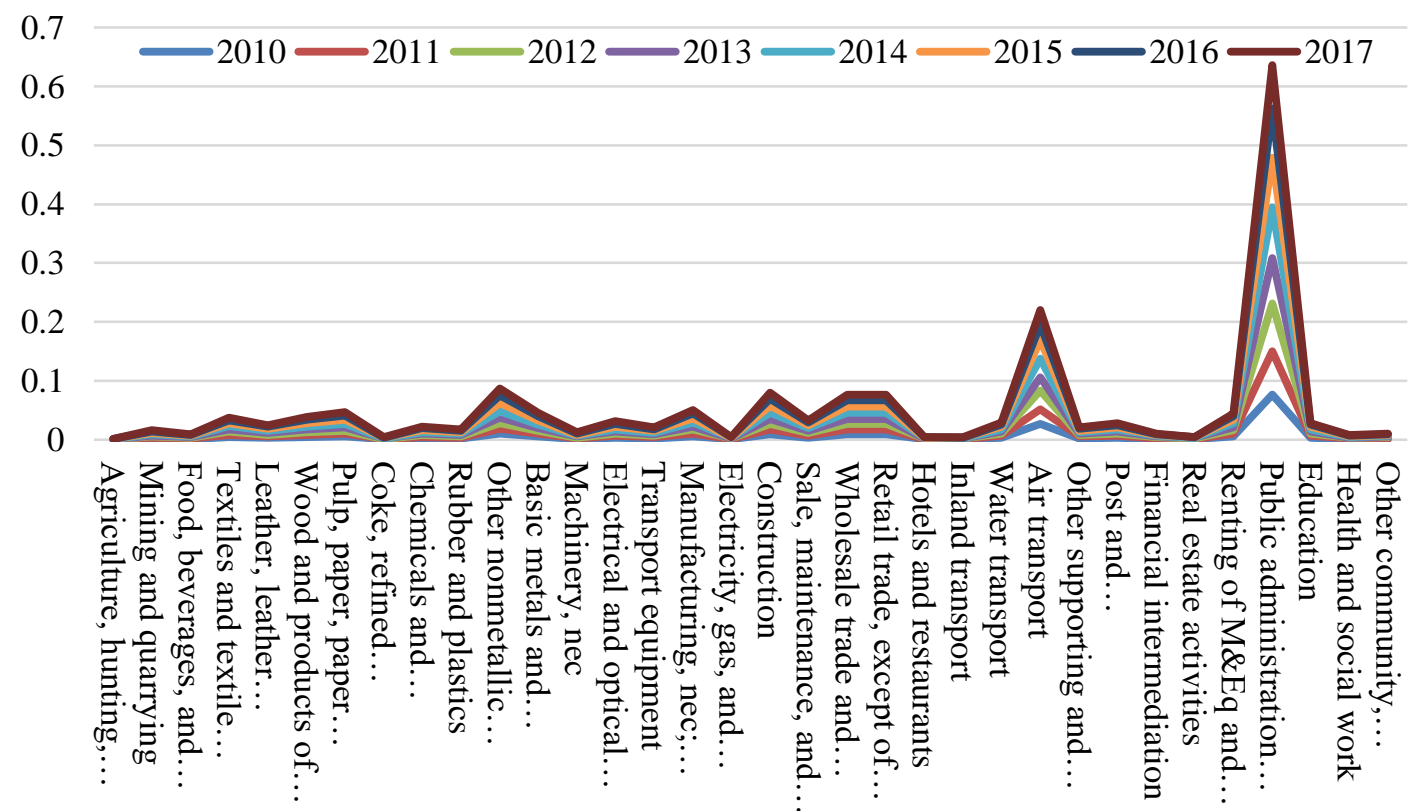

Figure 5 Output Share of the Hotel and Restaurant Industry to Other Sectors

Source: Asian Development Bank database, calculated from matrix technology (A).

Table 4. P-P test in level degree \& First Difference

\begin{tabular}{llll}
\hline Variable & P-value & Result & Degree \\
\hline GDP Hotel and Restaurant (Tourism) & 0.4683 & Non-Stationarity & Level \\
GDP Government & 0.4324 & Non-Stationarity & Level \\
GDP Hotel and Restaurant (Tourism) & 0.0000 & Stationarity & First Difference \\
GDP Government & 0.0001 & Stationarity & First Difference \\
\hline \multirow{2}{*}{ Government Sector: $:$ ECM Government $=$ Bo } & + ECM Government \\
T-stat (P-value) $\quad: \quad 12)$
\end{tabular}

Before measuring the cointegrating equation, heteroscedasticity, autocorrelation, and multicollinearity are examined from the original model. The test results from B-G heteroscedasticity and B-G serial correlation are not significant (B-G Heteroscedasticity P-value $=0.3052, \mathrm{~B}-\mathrm{G}$ serial correlation P-value $=0.9268)$. Hence, error noises are not present. VIF shows a score of 1 (VIF tourism $=1)$; hence multicollinearity does not exist. With that cointegration, the econometric relationship of the observed variables uses ECM, as shown in Table 6.

In table 6 , the coefficient is more than 1 , as the government output can be controlled by the policymakers, while tourism output follows the market mechanism. Nonetheless, as suggested by Narayan \& Smyth (2006), that ECM is allowed to be more than 1, as long as the t-statistics is significant. To validate post-estimation, we also conducted the Engel-Granger cointegration tests by transforming the model with cointegration transformation estimation, as suggested by Chancharoenchai (2015) as Table 7. 
Table 5. ECM result the determinants of government Output (first difference)

\begin{tabular}{cc}
\hline Variables & $\begin{array}{c}\text { Coefficient } \\
(\mathrm{t}-\text {-statistics })\end{array}$ \\
\hline$\Delta$ tourism output & $\begin{array}{c}0.950199 * * \\
(2.089753)\end{array}$ \\
\hline ECT (t-1) & $-1.006913 * *$ \\
& $(-4.130367)$ \\
\hline$\Delta$ government $(-1)$ & 0.019619 \\
& $(0.124260)$ \\
\hline significant at $10 \%, * *$ significant at $5 \%$ & $51.98 \%$ \\
\hline
\end{tabular}

Table 6. ECM validization

\begin{tabular}{lll}
\hline Test & Value (t-stat) & P-value \\
\hline Engel-Granger Cointegration t-statistics & 6.119 & $0.0032^{* *}$ \\
\hline$* *)$ significant at 5\% & &
\end{tabular}

**) significant at $5 \%$

The result shows a validated error correction model. Hence, it can be further continued for data interpretation. From that equation, while the lag of the past government output is not significant, the cointegrating factor has a negative and significant influence on the share of government output (first difference). If the cointegrating factor negatively influences the dependent variable, the cointegrating equation is still appropriate (Enders, 2014; IHS Markit, 2017). Past studies reinforce the positive and significant influence of the tourism economy on government retribution and administration (Djulius, 2018; OECD, 2020). These government revenues can induce more share economic output through greater development of social and physical infrastructures as well as some business incentives (OECD, 2020). This research revealed the significant and positive effect of tourism share output on the government's share output. This research confirms the results of past studies.

\section{CONCLUSION AND RECOMMENDATION}

This paper aims to analyze the role of the tourism sector in the Indonesian economy, utilizing the input-output and error-correction model approach. The input-output result shows that the tourism sector ranks ninth among the Indonesian economy's largest input users. Moreover, the industry depends on other sectors' output, namely the manufacturing, agriculture, and trading sectors. Then, based on the output contribution to the entire economy, the tourism sector mainly generates income for the air transport industry and the government sector in the form of retribution and social security insurance.

Through further analysis using the error-correction model, the study seeks the relationship between tourism and other sectors mentioned above. The result shows that the manufacturing sector's output has a significant and positive relationship with the tourism sector, while the tourism sector significantly and positively affects the government retributions. However, the agriculture sector demonstrates a negative and significant relationship with tourism output.

Based on this result, the study concludes the importance of the manufacturing sector enhancement to foster tourism sector growth, while there is a tradeoff between agriculture development and tourism. One could assume that the tradeoff happens due to the factors of production competition, as the agriculture and tourism sector (hotels and restaurants) requires land for its activities. However, agricultural productivity improvement is still vital for the overall 
Indonesian economy, as it shows through the input-output analysis that the agriculture sector's output is an essential input for the tourism sector, and the agricultural sector is effective in reducing the country's inequality (González-Gordon et al. 2019; Raeskyesa, 2020). In this context, it may be beneficial to consider Agri-Food tourism (Liu, Yen, Tsai, \& Lo, 2017) and nature tourism (Allen, 2015).

This study still has some limitations, such as its application of causality analysis to investigate how the tourism sector's growth affects other economic sectors in the Indonesian economy. Future research could also extend panel data and consider other variables to extend the analysis of backward and forward economic linkages of tourism with other economic sectors.

\section{ACKNOWLEDGEMENT}

The authors would like to thank the two reviewers for the helpful comments and the Research Office from the School of Business and Economics Universitas Prasetiya Mulya.

\section{REFERENCES}

Allen, K. E. (2015). Trade-offs in nature tourism. Ecology and Society, 20(1), 1-10.

Amir, H., \& Nazara, S. (2005). Analisis Perubahan Struktur Ekonomi (Economic Landscape) dan Kebijakan Strategi Pembangunan Jawa Timur Tahun 1994 dan 2000: Analisis InputOutput. Jurnal Ekonomi Dan Pembangunan Indonesia, 5(2), 37-55.

Anas, R., Tamin, O. Z., \& Wibowo, S. S. (2015). Applying input-output model to estimate the broader economic benefits of Cipularang Tollroad Investment to Bandung District. Procedia Engineering, 125, 489-497.

Antara, M. (2008). Keterkaitan usaha kecil sektor pariwisata dengan sektor-sektor ekonomi lainnya di Provinsi Bali: suatu pendekatan model input-output. SOCA, 8(1), 1-22.

Arianti, D. (2014). Pengaruh Sektor Pariwisata Terhadap Perekonomian dan Keruangan Kota Bukittinggi (Pendekatan Analisis Input Output). Jurnal Wilayah Dan Lingkungan, 2(3), 183-196.

Atan, S., \& Arslanturk, Y. (2012). Tourism and Economic Growth Nexus: An Input Output Analysis in Turkey. Procedia - Social and Behavioral Sciences, 62, 952-956.

BAPPENAS. (2015). Rencana Pembangunan Jangka Menengah Nasional (RPJMN) 2015-2019. Jakarta. Retrieved from https://www.bappenas.go.id/id/data-dan-informasiutama/dokumen-perencanaan-dan-pelaksanaan/dokumen-rencana-pembangunannasional/rpjp-2005-2025/rpjmn-2015-2019/

Blake, A., Sinclair, M. T., \& Sugiyarto, G. (2003). Quantifying the Impact of Foot and Mouth Disease on Tourism and the UK Economy. Tourism Economics, 9(4), 449-465.

Chancharoenchai, K. (2015). Exploring long-run relationship and error correction of Thai output and price. Applied Economics Journal, 22(1), 79-101.

Djulius, H. (2018). Strategies for increasing tax revenue in tourism sector. Economic Journal of Emerging Markets, 10(1), 61-68.

Dogru, T., \& Bulut, U. (2018). Is tourism an engine for economic recovery? Theory and empirical evidence. Tourism Management, 67, 425-434.

Enders, W. (2014). Applied Econometric Time Series (Wiley Series in Probability and Statistics) 4th Edition. MA: Wiley. 
Engle, R., \& Granger, C. (1987). Cointegration and Error Correcting: Representation, Estimation, Testing. Econometrica, 55(2), 251-277.

Fabinyi, M. (2020). The role of land tenure in livelihood transitions from fishingto tourism. Maritime Studies, 19(1), 29-39.

Fafurida. (2012). Analysis of Intersectoral Linkages in Semarang Regency. Economic Journal of Emerging Markets, 4(1), 15-24.

FAO. (2020). Working towards sustainable oil-palm crops. Retrieved from http://www.fao.org/world-agriculture-watch/our-program/idn/en/

González-Gordón, I., \& Resosudarmo, B. P. (2019). A sectoral growth-income inequality nexus in Indonesia. Regional Science Policy \& Practice, 11(1), 123-139.

Gujarati, D., \& Porter, D. (2008). Basic Econometrics (5th editio). New York: McGraw-Hill Education.

Hadi, W. (2019). Menggali potensi kampung wisata di kota Yogyakarta sebagai daya tarik wisatawan. Journal of Tourism and Economic, 2(2), 129-139.

Hasudungan, A., \& Neilson, J. (2020). The Institutional Environment of the Palm Oil Value Chain and Its Impact on Community Development in Kapuas Hulu, Indonesia. Southeast Asian Studies, 9(3), 439-465.

IHS Markit. (2017). EViews 10 Getting Started. Irvine CA: IHS Markit Global Inc (Corporation). Retrieved from http://eviews.com/download/EViews 10 Getting Started.pdf

Jansen, H., Stern, A., \& Weiss, E. (2015). Linking Farmers and Agro-processors to the Tourism Industry in the Eastern Caribbean. Washington DC. Retrieved from http://documents.worldbank.org/curated/en/261991467997876693/pdf/ACS16280-WPREPLACEMENT-Linking-Farmers-and-Agro-processors-to-the-Tourism-Industry-inthe-Eastern-Caribbean.pdf

Kim, H., \& Kim, B. G. (2015). Economic impacts of the hotel industry: An input-output analysis. Tourism Review, 70(2), 132-149.

Kronenberg, K., Fuchs, M., \& Lexhagen, M. (2018). A multi-period perspective on tourism's economic contribution - a regional input-output analysis for Sweden. Tourism Review, 73(1), 94-110.

Krugman, P., Obstfeld, M., \& Melitz, M. (2015). International Economics: Theory and Policy. United States: Pearson.

Liu, C., \& He, S. (2016). Input-output structures of the Australian construction industry. Construction Economics and Building, 16(2), 56-70.

Liu, S.-Y., Yen, C.-Y., Tsai, K.-N., \& Lo, W.-S. (2017). A Conceptual Framework for Agri-Food Tourism as an Eco-Innovation Strategy in Small Farms. Sustainability, 9(10), 1683.

Malba, E., \& Taher, I. M. (2016). Analisis Input-Output Atas Dampak Sektor Pariwisata terhadap Perekonomian Maluku. Bina Ekonomi, 20(2), 213-229.

Miller, R., \& Blair, P. (2009). Input-output Analysis: Foundations and Extensions. Cambridge: Cambridge University Press.

Ministry of Tourism. (2018a). Laporan Akuntabilitas Kinerja Kementerian Pariwisata tahun 2018. Jakarta.

Ministry of Tourism. (2018b). Rencana Strategis 2018-2019 Kementerian Pariwisata. Jakarta. 
Narayan, P. K., \& Smyth, R. (2006). What determines migration flows from low-income to highincome countries? An empirical investigation of Fiji-U.S. migration 1972-2001. Contemporary Economic Policy, 24(2), 332-342.

Nazara, S. (2005). Analisis Input Output. Depok: Lembaga Penerbit Fakultas Ekonomi Universitas Indonesia.

Neilson, J., Pritchard, B., Fold, N., \& Dwiartama, A. (2018). Lead Firms in the Cocoa-Chocolate Global Production Network: An Assessment of the Deductive Capabilities of GPN 2.0. Economic Geography, 94(1-25).

OECD. (2020). OECD Tourism Trends and Policies 2020. OECD.

Patera, I. M., Sukarsa, I. M., \& Wiranatha, A. S. (2015). Tourism and Poverty in Badung Regency, Bali. E-Journal of Tourism; , 2(2), 84-95.

Pratama, R., \& Rosyidie, A. (2017). Social Impacts of Tourism Industry Caused by Agricultural Land Use Change in Tourism Infrastructure Development in Ubud Region, Gianyar Regency, Province of Bali, Indonesia. ASEAN Journal on Hospitality and Tourism, 15(1), 36-47.

Pratt, S. (2015). The economic impact of tourism in SIDS. Annals of Tourism Research, 52, 148160.

Raeskyesa, D. G. S. (2020). Sectoral Growth and Income Inequality in ASEAN-5 Countries: Case of Low-Middle Income Economies. JAS (Journal of ASEAN Studies), 8(1), 1-13.

Raeskyesa, D., Suryandaru, R., \& Kadarusman, Y. (2019). Analysis on Growth Pattern and Economic Sectors in Bali Province. Analysis on Growth Pattern and Economic Sectors in Bali Province, 11(2), 45-56.

Sá, C., Martins, A., \& Gomes, C. (2014). Tax morale, Occupation and Income Level: An Analysis of Portuguese Taxpayers. Journal of Economics, Business and Management, 2(2), 112116.

Saputra, A., \& Kurniawan, A. (2012). Peran sektor pariwisata dalam perekonomian wilayah provinsi daerah istimewa yogyakarta. Jurnal Bumi Indonesia, 1(12), 19-26.

Schouten, G., \& Bitzer, V. (2015). The emergence of Southern standards in agricultural value chains: A new trend in sustainability governance? Ecological Economics, 120, 175-184.

Shahzad, S. J. H., Shahbaz, M., Ferrer, R., \& Kumar, R. R. (2017). Tourism-led growth hypothesis in the top ten tourist destinations: New evidence using the quantile-on-quantile approach. Tourism Management, 60, 223-232.

Singagerda, F. S., \& Septarina, L. (2016). The Economy of Tourism and Its Impact to Other Sectors in Lampung Province. Journal of Indonesian Tourism and Development Studies, 4(3), $129-136$.

Statistics Indonesia. (2019). Statistik Indonesia: Pariwisata. Retrieved April 4, 2020, from Badan Pusat Statistik (Indonesian Statistics) website: https://www.bps.go.id/publication/2019/07/04/daac1ba18cae1e90706ee58a/statistikindonesia-2019.html

Suharto. (2019). Strategi Pengelolaan Desa Wisata Jamu Kiringan, Kecamatan Jetis, Kabupaten Bantul. Journal of Tourism and Economic, 2(2), 108-117.

Surugiu, C. (2009). The Economic Impact of Tourism. An Input-Output Analysis. Romanian Journal of Economics, 29, 2(38)), 142-161.

Todaro, M., \& Smith, S. (2012). Economic development (11th ed.). Boston: Addison-Wesley. 
UNWTO. (2019). UNWTO \& WTM Ministers' Summit 2019: Technology for Rural Development.

World Travel and Tourism Council. (2019). Economic Impact Reports. Retrieved March 20, 2021, from https://wttc.org/Research/Economic-Impact

Xu, R., Xu, L., \& Xu, B. (2016). Assessing CO 2 emissions in China's iron and steel industry: Evidence from quantile regression approach. Journal of Cleaner Production, 152, 259270. 